\title{
Organizar a Desordem: Raízes do Brasil em 1936*
}

\author{
Luiz Feldman
}

Instituto Rio Branco, Brasília, DF, Brasil. E-mail: lfeldman@superig.com.br

$\mathrm{O}$ parágrafo de abertura da primeira edição de Raízes do Brasil é uma cifra de todo o livro. Em quatro frases intricadas, Sergio Buarque de Holanda traça as grandes linhas de seu esforço de interpretação e aponta uma tensão central de sua obra de estreia. Indo diretamente ao texto ${ }^{1}$ :

Todo estudo compreensivo da sociedade brasileira há de destacar o fato verdadeiramente fundamental de constituirmos o único esforço bem-sucedido, e em larga escala, de transplantação da cultura europeia para uma zona de clima tropical e subtropical. Sobre território que, povoado com a mesma densidade da Bélgica, chegaria a comportar um número de habitantes igual ao da população atual do globo, vivemos uma experiência em símile. Trazendo de países distantes as nossas formas de vida, nossas instituições e nossa visão do mundo, e timbrando em manter tudo isso em um ambiente muitas vezes desfavorável e hostil, somos ainda uns desterrados em nossa terra. Podemos construir obras excelentes, enriquecer nossa humanidade de aspectos novos e imprevistos, elevar até à perfeição o tipo de cultura que representamos: o certo é que todo o fruto de nosso trabalho ou de nossa preguiça parti-

\footnotetext{
* Na preparação deste artigo, o autor beneficiou-se das indicações e das críticas de Luiz Costa Lima, Wanderley Guilherme dos Santos, Maria Regina Soares de Lima, Ricardo Benzaquen de Araújo, Robert Wegner, Christian Lynch, João Cezar de Castro Rocha, Pedro Meira Monteiro e Victor Coutinho Lage. Erros e omissões são de inteira responsabilidade do autor.
}

DADOS - Revista de Ciências Sociais, Rio de Janeiro, vol. 58, no-4, 2015, pp. 1131 a 1168. 
cipa fatalmente de um estilo e de um sistema de evoluções naturais a outro clima e a outra paisagem (Holanda, 1936:3).

O trecho contém enunciados-chave do livro, mas só se decodifica por completo ao cabo da leitura de todo o ensaio. Por esse ponto de vista, as passagens se esclarecem e ganham espessura conceitual. Na primeira frase, a cultura europeia transportada com êxito para os trópicos pode ser detalhada como a cultura proveniente da Península Ibérica, que se marca pelo apego generalizado aos valores da personalidade e pela consequente iminência do estado de anarquia social. Na segunda, a referência à plausibilidade de que o território brasileiro viesse a abrigar número de habitantes igual àquele então existente em todo o planeta pode ser relacionada ao elogio da cordialidade, caracterizada entre outros pela hospitalidade, como contribuição do Brasil ao mundo moderno. Na terceira frase, o tom benévolo da narrativa é alternado com o diagnóstico crítico do desterro, isto é, a incompatibilidade entre os costumes e doutrinas importados pelos bacharéis do século XIX (sobretudo a democracia liberal) e o ambiente personalista e cordial que acaba de ser mencionado. Na última, a constatação algo desolada de que, a persistir o desterro, a vitalidade cultural emprestada ao país pela cordialidade será desperdiçada pode ser relacionada à crítica contundente do autor aos bovarismos artísticos e políticos negadores do caráter nacional.

Essa sumária reconstrução do alcance e do jogo dos enunciados contidos no parágrafo de abertura de Raízes do Brasil sugere a pertinência de um modo de leitura dessa obra que lhe assinale a qualidade de ensaio e, por isso, busque compreender seu conteúdo sem descurar da análise de sua forma (Wegner, 2006). Uma característica da escrita do livro que cumpre ressaltar é a alternância da perspectiva adotada para a avaliação de enunciados propostos. O ponto é ilustrado pela inadvertida mudança do tom elogioso para o tom crítico na metade do parágrafo inicial. Além de surpresas, esse procedimento formal contribui para a criação de ambiguidades. A principal delas dirá respeito ao papel da herança colonial na construção do Brasil moderno. Nesse sentido, a leitura espessa do parágrafo de abertura aponta os contornos de um dilema no centro do argumento de Raízes do Brasil: como fundar uma organização política respeitável em uma sociedade eivada de elementos anárquicos sem reprimir o substrato cultural que singulariza os brasileiros e distingue seu lugar no concerto das nações? 
Esses não são os termos em que se costuma apresentar o impasse político de Raízes do Brasil, em geral associado aos obstáculos para a democratização do país. Contudo, como alguns estudos já procuraram evidenciar (Eugênio, 2011; Feldman, 2013; Nicodemo, 2014; Pesavento, 2005; Rocha, 2004; Waizbort, 2011), a mensagem do livro foi significativamente alterada pelas modificações realizadas para sua segunda e terceira edições, vindas a lume respectivamente em 1948 e 1956. Reconstruir o dilema político apresentado pelo volume inaugural da coleção Documentos Brasileiros da Editora José Olympio, com lançamento marcado para 20 de outubro de 1936 (Franzini, 2010), é o propósito deste artigo.

Para tanto, o trabalho examinará o diálogo de Sergio Buarque com Francisco José Oliveira Vianna e com Gilberto Freyre, dois autores cujas reflexões contribuíram para a formulação daquele dilema de transformação da anarquia personalista em civilidade política sem supressão do caráter cordial da população. A interlocução desses três autores já foi explorada com proveito (Ferreira, 1996), mas raramente o foi do ponto de vista do texto original de Raízes do Brasil, e ainda assim apenas parcialmente (cf. Brasil Jr. e Botelho, 2011; Bastos, 2005). Esse empreendimento contribuirá para lançar outra luz sobre as afinidades e desacordos entre eles, sem, contudo, pretender esgotar, nem mesmo mapear a gama de discussões encetadas por Sergio Buarque com outros autores brasileiros e estrangeiros de seu tempo.

O artigo se dividirá em quatro seções, que discutirão grosso modo as duas metades do parágrafo inicial, que também são as duas metades do livro. De um lado, o enunciado do desterro, com seu diagnóstico (primeira seção do artigo) e seu prognóstico (quarta seção). De outro, o enunciado da cordialidade, visto sob ótica negativa (segunda seção) e depois sob ótica positiva (terceira seção). A seção inicial identificará no diálogo frequentemente velado de Sergio Buarque com Oliveira Vianna a formulação do que se designou um diagnóstico do desterro. A seção seguinte cotejará insolidariedade e cordialidade, conceitos centrais no quadro privatista da realidade brasileira composto tanto por Oliveira Vianna quanto por Sergio Buarque. A penúltima seção acompanhará o engajamento com a obra de Gilberto Freyre, focando-se no reconhecimento de uma herança ibérica e na elaboração de um elogio da cordialidade. A seção final analisará a tentativa de solução do problema do desterro por meio do diálogo com Gilberto Freyre e o caminho afinal tomado para equacionar o dilema. 
Aproximando e contrastando o texto original do clássico de Sergio Buarque com escritos desses pensadores, compreende-se um pouco melhor as certezas e as inquietações de uma obra longamente meditada e enfim publicada, segundo o relato do próprio autor, após quase uma década de preparação (Holanda, 1979:29). Um benefício desse estudo será a percepção de que Raízes do Brasil não foi sempre o símbolo de crítica ao legado ibérico em que depois foi erigido. A consulta à edição princeps revela uma grande ambiguidade do autor em relação ao passado. A cifra do parágrafo de abertura desvenda-se, ao correr das páginas, tanto pela afirmação otimista da identidade cordial quanto pela indagação desassossegada sobre as condições de implantação da civilidade. O oximoro com que Sergio Buarque sintetizou o dilema político de seu livro empregava sintomaticamente, como verbo, o vocábulo que também designava a forma de sua escrita: tratava-se de "ensaiar a organização de nossa desordem" (Holanda, 1936:176).

\section{O PECADO DE CEM ANOS}

Em março de 1935, Sergio Buarque publicou na revista Espelho o artigo "Corpo e Alma do Brasil: Ensaio de Psicologia Social", espécie de trailer de Raizes do Brasil. Uma passagem desse texto contém formulação fundamental do diagnóstico da disjunção entre instituições políticas e realidade social:

O fato é que a ideologia impessoal e antinatural do liberalismo democrático, com as suas maiúsculas impressionantes e com as suas fórmulas abstratas, jamais se naturalizou entre nós. Só assimilamos efetivamente esses princípios até o ponto em que coincidam com a negação pura e simples de uma autoridade incômoda, em que confirmavam nosso instintivo horror às hierarquias e em que nos permitiam tratar com intimidade os governantes. A democracia no Brasil foi sempre um lamentável mal entendido. Uma aristocracia rural e semifeudal importou-a e tratou de acomodar-se como pôde aos seus preceitos que tinham sido justamente a bandeira de combate da burguesia europeia, e isso somente porque esses preceitos pareciam os mais acertados para os tempos e eram exaltados nos livros e nos discursos. O pecado original dessa atitude livresca nunca mais se apagou de nossa vida pública (Holanda, 2006:407).

A passagem foi aproveitada no sexto capítulo do livro lançado no ano seguinte. Mas, na redação de 1936, o trecho sofre alterações no começo 
e no fim: acrescenta-se uma nova frase no início e exclui-se a frase final. Essas duas modificações do artigo de 1935 para o livro de 1936 merecem atenção.

A frase que passa a anteceder o trecho é a seguinte: "Trouxemos de terras estranhas um sistema completo e acabado de preceitos, sem saber até que ponto se ajustam à vida brasileira" (Holanda, 1936:122). É possível observar a identidade substantiva e até formal dessa nova frase com a terceira frase do parágrafo de abertura do livro. O início do trecho do sexto capítulo ("Trouxemos de terras estranhas...") é uma paráfrase do início do trecho da abertura do livro ("Trazendo de países distantes..."). Substantivamente, reitera-se a censura à importação de doutrinas incompatíveis com a realidade brasileira. Essa censura será a tônica da discussão do capítulo seis de Raízes do Brasil. A passagem escrita em 1935 e transcrita com alterações em 1936 enuncia uma dinâmica em que o liberalismo democrático é assimilado seletivamente em proveito do personalismo (incômodo com a autoridade) e da cordialidade (aversão à hierarquia, desejo de intimidade). (A correlação desses sentimentos com essas categorias será esclarecida adiante.) O resultado é que, em Raízes, a ligação direta entre o primeiro parágrafo e o sexto capítulo associa o desterro não somente à importação de ideias estranhas, mas à dinâmica em que as doutrinas importadas são reprocessadas à conveniência das forças orgânicas da sociedade local.

Considere-se agora a segunda modificação sofrida pela passagem em análise. Na frase final do raciocínio de 1935, afirmava-se que a "atitude livresca" - ou "bovarismo", expressão também usada por Sergio Buarque (ibidem:130) - era um "pecado original" da vida política brasileira. A figura do "pecado original" ganha um significado específico à luz do opúsculo O Idealismo na Evolução Política do Império e da Repúbli$c a$, publicado em 1922 por Oliveira Vianna. Lançada na coleção do centenário da Independência editada por O Estado de S. Paulo, a pequena encadernação consta ainda hoje na biblioteca de Sergio Buarque na Universidade Estadual de Campinas.

Nessa obra, Oliveira Vianna apontava a existência no Brasil de um antigo conflito entre quixotismo e espírito de clã. Segundo o autor fluminense,

O quixotismo é um sentimento todo impregnado de intelectualismo, em cuja gênese dominam os fatores imaginativos; e, portanto, um sentimento fraco, de pequena energia emocional. O sentimento de clã, ao 
contrário, é vivaz, enérgico, todo feito de materialidade; poderoso [...] pela sua energia emocional, porque está nas tradições e costumes do povo (Vianna, 1922:92).

O embate entre quixotismo e clanismo era desigual: "aquele tem que ceder e recuar diante da rude instintividade do poderoso sentimento oriundo do espírito de clã" (idem). A dissolução das doutrinas estrangeiras pela realidade local era a razão de fundo pela qual as tentativas de organização política do Brasil nos moldes do federalismo norteamericano, do parlamentarismo inglês ou do liberalismo democrático francês haviam fracassado no Império e na República. O conflito entre quixotismo e espírito de clã estava na raiz do que Oliveira Vianna designava "idealismo utópico", isto é, um "conjunto de aspirações políticas em íntimo desacordo com as condições reais e orgânicas da sociedade que pretendem reger e dirigir" (ibidem:14). E o idealismo utópico, sentenciava, "tem sido o nosso grande pecado de cem anos" (ibidem:17).

Admitindo-se que Sergio Buarque tenha lido o opúsculo de Oliveira Vianna, o que parece fora de dúvida, seria difícil desconsiderar o indício de uma citação velada a O Idealismo na Evolução Política do Império e da República no artigo de 1935. O "pecado original" mencionado por Sergio Buarque remontava ao início da vida política independente no Brasil, ou pouco antes, com a transmigração da Corte portuguesa. Tratava-se do mesmo período coberto pelo "pecado de cem anos" denunciado no texto de Oliveira Vianna publicado no centenário da Independência. Esse autor retomaria o mote cinco anos mais tarde, no livro $O$ Idealismo da Constituição. Censura aí o idealismo utópico que, "há cem anos, vem 'sonhando' a democracia no Brasil”' (Vianna, 1927:10). E lamenta o fato de que

Nenhum dos nossos ideais rescende o doce perfume da nossa terra natal. Trazem-nos sempre à nossa lembrança uma evocação de estranhas terras, de outros climas, de outros sóis, de outras pátrias. Neste ponto de vista, somos deracinés: os nossos ideais não se alimentam da nossa seiva, não se radicam na nossa vida, não se embebem na nossa realidade, não mergulham na nossa história (ibidem:141).

O Idealismo da Constituição não consta da biblioteca hoje catalogada de Sergio Buarque, mas não é implausível que ele o tivesse lido. Já se apontou nas entrelinhas de Raízes do Brasil, e com razão, "diálogos implícitos" com O Idealismo da Constituição (Nogueira, 2002). Pode-se 
imaginar, nessa linha, uma interlocução do livro de 1927 e o de 1936, com a fala do primeiro ("somos deracinés...") e a réplica do segundo ("somos ainda uns desterrados..."). Nessas locuções sucessivas, o advérbio de tempo "ainda" evocaria uma atualização do diagnóstico do desterro, ou desenraizamento, no vocábulo francês.

A coincidência entre expressões usadas por Sergio Buarque e termos empregados por Oliveira Vianna ("pecado", "desterro") se dá sempre no contexto preciso da discussão acerca do caráter estéril ou contraproducente do "idealismo utópico". O engajamento com a obra do autor fluminense não se limitava ao empréstimo de expressões. Apanha-se no diagnóstico do desterro descrito por Sergio Buarque em 1935 o essencial da lógica proposta por Oliveira Vianna em 1922. Na interação das doutrinas estrangeiras com a realidade nacional, esta neutraliza aquelas e as utiliza em seu proveito. $\mathrm{O}$ "íntimo desacordo" entre aspirações políticas e condições sociais resolvia-se sempre em favor destas. $\mathrm{Ou}$, nos termos de Sergio Buarque, o liberalismo democrático era efetivamente assimilado apenas até o ponto em que atendia ao personalismo e à cordialidade. O que parece revestir a obra de Oliveira Vianna de especial interesse para o autor de Raízes do Brasil é a tese de que as condições em que se processara a formação colonial do país explicavam a falta de coesão social que, por sua vez, gerava o fracasso da implantação de modelos políticos estrangeiros. Essa tese não se encontra, como tal, em O Idealismo na Evolução Política do Império e da República, mas pode ser subentendida no fato de que Oliveira Vianna postulasse o espírito de clã, um dos conceitos centrais da análise histórica de Populações Meridionais do Brasil, como polo do conflito com o quixotismo.

\section{UMA IMPRESSÃO DESOLANTE}

O diálogo de Sergio Buarque com Oliveira Vianna acerca da tese da existência de uma relação entre formação colonial e falta de coesão social no país extrapola os limites estritos da questão do desterro. Sergio Buarque engajava um ponto capital de Populações Meridionais do Brasil, obra maior de Oliveira Vianna. O resultado dessa interlocução já foi descrito como um "encontro de interpretações" (Wegner e Lima, 2004), em que os autores explicam similarmente o país ao atribuírem papel de destaque ao ruralismo. O ponto de contato, e mesmo de comensurabilidade, entre as duas narrativas é dado pelos conceitos de insolidariedade e cordialidade. 
Há em Raízes do Brasil apenas duas referências ostensivas a Oliveira Vianna, e de nenhuma delas se concluiria pela existência de um diálogo enriquecedor entre os dois autores. Elas terão relevância pela ótica da aproximação de Sergio Buarque a Gilberto Freyre, e é preciso aquilatá-las antes de as colocar em perspectiva. A primeira referência, única no corpo do texto, encontra-se no sétimo capítulo: "No Brasil, e não só no Brasil, iberismo e agrarismo confundem-se, apesar do que têm dito em contrário alguns estudiosos eminentes, entre outros o snr. Oliveira Vianna" (Holanda, 1936:137). A segunda referência encontra-se em uma nota ao capítulo três. Antes da indicação da nota há a afirmação de que o ruralismo era uma característica típica da projeção ultramarina portuguesa. "E vale a pena assinalar-se isso", segue o texto, "pois parece mais cômodo, e talvez mais lisonjeiro à vaidade nacional de alguns, a crença, nesse caso, em certa misteriosa 'força centrífuga' própria ao meio americano e que tivesse compelido nossa aristocracia rural a abandonar a cidade pelo isolamento dos engenhos e pela vida rústica das terras de criação" (ibidem:55). Na nota (que, por sua extensão, foi posta ao fim do volume), o destinatário da crítica era nominado: devia-se "ao snr. F. J. Oliveira Vianna" a "teoria artificiosa e extravagante da "força centrífuga'" (ibidem:166). O novo emprego do respeitoso pronome de tratamento "snr." não esconde, dessa feita, a mordacidade da crítica ao ufanismo e ao despropósito atribuídos à teoria em questão. Contra-arrestava-se que o desequilíbrio entre riqueza rural e miséria urbana já se verificava em Portugal (ibidem:167-168). E, o que é ainda mais importante e se lia em outro passo do livro, o desequilíbrio resultava no Brasil da "fisionomia mercantil" da colonização, fruto do espírito de aventura com que se conduziu o empreendimento ultramarino (ibidem:79-80). O autor concluía a nota tecendo considerações, aliás ainda pertinentes, acerca da "obsessão do arianismo" de Oliveira Vianna (idem:168).

O golpe assestado contra a tese do ruralismo apresentada em Populações Meridionais do Brasil era certeiro. Atingia um ponto de partida da narrativa histórica de Oliveira Vianna: a tendência do meio americano de impelir a nobreza colonial para o "rude isolamento" dos campos, diferenciando-se do "espírito peninsular" pela ação tenaz do "conformismo rural" (1920:13-18). Outro ponto do raciocínio do autor fluminense, a tese de que a autonomia do grande domínio rural impedia o desenvolvimento de outras áreas da sociedade, também mereceu reparos. Embora Oliveira Vianna não seja citado, sua asserção de que o caráter absorvente do latifúndio conferia "fisionomia característica [a]o 
nosso interior rural" (idem:122) terá sido o alvo da observação de que a autonomia dos grandes domínios "não é [...] um privilégio do Brasil colonial" (Holanda, 1936:86-87). O que distinguia as fazendas brasileiras era, na verdade, "o tipo de família organizada dentro das normas do velho direito romano-canônico, mantido na Península Ibérica através das gerações" (ibidem:87), designado páginas adiante como o "tipo primitivo da família patriarcal" (ibidem:99). Pode-se identificar nesse passo um sinal do diálogo com Gilberto Freyre (1933) sobre a formação portuguesa e patriarcal do Brasil, objeto da próxima seção. No geral, é perceptível o sentido das manobras de Sergio Buarque. Cada objeção sua à diferenciação entre o brasileiro e o português é acompanhada por uma reiteração do vínculo do Brasil com a cultura ibérica. A ligação já fora categoricamente definida no primeiro capítulo: “a verdade [...] é que ainda nos associa à Península Ibérica, e a Portugal especialmente, uma tradição longa e viva, bastante viva para nutrir até hoje uma alma comum [...]. Podemos dizer que de lá nos veio a forma atual de nossa cultura" (ibidem:15).

Contra o "centrifugismo rural", a "alma comum". De fato, o ponto de partida de Sergio Buarque era nitidamente diverso do de Oliveira Vianna, e as consequências da divergência não eram desprezíveis em se tratando - caso de Raízes do Brasil - de compor um quadro da cultura brasileira. (Tome-se como exemplo o fato de que a cronologia usada em Populações Meridionais do Brasil identifica o início da colonização como um marco zero histórico. Assim, não se lê sobre o "século XIX", mas sobre o "IV século". Sergio Buarque, em troca, opera com calendário cristão.) Raízes do Brasil rejeitava uma explicação situacional da colonização do Novo Mundo, em favor de uma explicação genética. Essas categorias, tributárias da discussão de Richard Morse (1965), iluminam a diferença entre a visão de que o ambiente americano moldava formas sociais originais (explicação situacional) e a visão de que as formas sociais nele estabelecidas não podiam deixar de ser vazadas na fôrma ibérica (explicação genética). O fato de que fossem críticas todas as referências ostensivas a Oliveira Vianna sugere um intuito de marcar posição no debate público da época afastando-se de um autor conhecido pela abordagem situacional. A exclusão da referência implícita ao "pecado de cem anos", feita em tom positivo no artigo de 1935, do trecho transposto sem outras modificações para Raízes do Brasil no ano seguinte poderia ser explicada na mesma chave. É sensível a inclusão, em Raízes, de um conjunto de argumentos genéticos (no sentido precisado acima) que não se tinham formulado claramente em "Corpo e 
Alma do Brasil". Esse é o caso, por exemplo, da discussão estruturada do personalismo como atributo ibérico, que está ausente em 1935, mas ocupa todo o primeiro capítulo do volume de 1936.

Ocorre que as divergências entre esses autores não anulam convergências provavelmente mais relevantes (Carvalho, 2002). A vocação privatista desenvolvida ao longo do passado rural e o desafio que ela representava para a fundação de uma ordem pública moderna são métricas comuns da reconstrução histórica de Populações Meridionais do Brasil e de Raizes do Brasil. As narrativas desses dois livros têm nexos similares: a fragmentação da população colonial em fazendas isoladas; o caráter absorvente das relações familiares aí desenvolvidas; a formação de uma sociabilidade baseada eminentemente em afetos; e a configuração de uma sociedade infensa à impessoalidade e carente de solidariedade em nível nacional.

As duas obras compartilham a avaliação de que os colonizadores do Brasil adaptaram-se bem ao novo meio. Para Oliveira Vianna, foi preciso ao português abandonar o perfil ibérico e conformar-se à vida rústica. Para Sergio Buarque, o êxito foi conquistado justamente devido ao iberismo. Animados pela ética de aventura, os lusos adaptaram-se com admirável plasticidade a um meio sujeito a múltiplas injunções de clima, ecologia, cultura e raça. "Procurando recriar aqui o meio de sua origem, fizeram-no com uma destreza que ainda não encontrou segundo exemplo na história" (Holanda, 1936:25). Apesar dos raciocínios distintos, os dois autores concordavam na avaliação da boa adaptação do português ao novo meio, o que explica porque viam a configuração fragmentária da sociedade colonial como uma resposta justificada aos desafios daquele período. Daí, entre outras razões, a simpatia com que Oliveira Vianna tratava a nobreza territorial na primeira metade de $P_{0}$ pulações Meridionais do Brasil (Bittencourt, 2011), e os bons olhos com que Sergio Buarque via os aventureiros portugueses (Wegner, 2014). Daí também a dificuldade que a herança colonial colocava quando considerada pela ótica da organização da ordem pública no Brasil. Por um lado, a visão positiva do legado histórico como que predispunha os autores a julgar estranhas à terra as doutrinas que começam a ser importadas no século XIX; por outro, eles não deixam de reconhecer o imperativo de dar algum tipo de forma moderna ao país gestado no privatismo. Nesse sentido, poder-se-ia cogitar serem as próprias narrativas de Populações e de Raízes que se desterrariam, ao porem em suspenso a herança colonial e se indagarem sobre o futuro. Isso se refleti- 
ria no fato de as duas narrativas não conseguirem disfarçar o que se denominou, no caso da segunda metade de Populações, uma "guinada" (Carvalho, 1993), e, no caso dos três últimos capítulos de Raízes, uma "tensão" (Wegner, 2000). A hipótese é instigante, mas terá que ser tratada com cautela, especialmente no caso do livro de Sergio Buarque.

Começando por Populações: para Oliveira Vianna, a dispersão geográfica dos núcleos de produção agrária disseminava e insulava os grupos humanos. A decorrência era que "a vida da família se reforça progressivamente e absorve toda a vida social em derredor. O grande senhor rural faz da sua casa solarenga o seu mundo" (Vianna, 1920:41). Essas condições herméticas favorecem a criação de uma nova identidade à altura do século XVIII, ou "III século": "Sente-se que o nosso tipo do homem rural - homo rusticus - [...] já se vai modelando por esse tempo, e diferenciando-se cada vez mais do tipo peninsular originário" (ibidem:16). A enunciação é aprofundada com uma afirmação de certa tonalidade essencialista: "Rural é o luso; mas, o luso não conhece a grande propriedade [...]. Nós somos o latifúndio" (ibidem:41). O fato geográfico do isolamento aparentava querer adensar-se em substância identitária. Oliveira Vianna não incursiona, contudo, no terreno da cultura. Sua sociologia preocupa-se eminentemente com a compreensão das condições de funcionamento das instituições políticas brasileiras e dispensa pouca atenção à busca de um self brasileiro, como até certo ponto o faria Sergio Buarque.

A narrativa de Populações Meridionais do Brasil prossegue com a descrição do papel do clanismo, cujos atributos negativos começam a criar o ambiente para a guinada narrativa do livro. O núcleo familiar latifundiário cedo se armou com um serviço de defesa, que veio a constituir o "clã fazendeiro". Sob o comando do grande proprietário de terras, a milícia rural tornou-se "um fator de turbulência social dos mais virulentos", e, a partir da descoberta de minas no século XVIII, se caracterizaria por uma "exacerbação caudilheira" (ibidem:72-73). O espírito de corpo dentro do clã era elevado, mas estiolava em seu exterior. Inexistiriam na colônia móveis de coesão social mais ampla, como inimigos externos ou hostilidades de classe. No Brasil, haveria sociabilidade sem chegar a haver sociedade. A solidariedade restringia-se à família e ao clã. Por isso, no campo, onde habitava a maioria da população e preservava-se íntegro ainda na atualidade o "caráter nacional" (Vianna, 1921:19), “a insolidariedade é completa. Não se descobre ali nenhum traço de associação entre vizinhos para fins de utilidade comum. Tudo 
nos dá uma impressão desolante de desarticulamento e desorganização" (Vianna, 1920:170).

Grassando já no nível vicinal ou municipal, a insolidariedade impedia a formação de uma consciência nacional. O homo rusticus, após quatro séculos, não tinha sequer consciência da solidariedade de aldeia ou tribo, como ocorreria em outras partes do mundo. O padrão de sociabilidade do homem rústico está bem descrito nesta afirmação: "Normalmente, o círculo da nossa simpatia ativa não vai, com efeito, além da solidariedade de clã. É a única solidariedade social que realmente sentimos, é a única que realmente praticamos" (ibidem:179). Explica-se, portanto, que os brasileiros não houvessem atingido a "intelectualização do conceito de Estado" (ibidem:302, grifo suprimido), isto é, a capacidade de discriminar entre o nível concreto e pessoal e o nível abstrato e impessoal da ação política.

A essa altura consuma-se a guinada narrativa de Populações Meridionais do Brasil. ${ }^{2}$ Identifica-se na reação do Segundo Reinado às oligarquias políticas um ponto de virada na história do país. Os protagonistas da narrativa deixam de ser os grandes proprietários e tornam-se o imperador D. Pedro II e os estadistas conservadores que pregaram a organização da ordem legal por meio da "trituração da caudilhagem" (ibidem:222; Carvalho, 2002). Esses estadistas não se teriam deixado iludir pela doutrina liberal implantada na Regência, que, defendendo a descentralização em uma sociedade cindida pelo espírito de clã, pusera o país na rota da fragmentação territorial. A defesa pelos conservadores do Estado unitário contra a "utopia" liberal fora obra de "idealismo orgânico", aquele "que só se orienta pela observação do povo e do meio" (Vianna, 1922:17). Em lugar do parlamentarismo britânico, da fórmula "o rei reina, mas não governa", os conservadores criaram um "parlamentarismo brasileiro", pelo qual "o rei reina, governa e administra". Agira-se, no Império, "fora" dos princípios constitucionais, ou mesmo "contra" eles (Vianna, 1925:96), com vistas à concentração de poderes. Essa solução, de "inegável hipocrisia" (Vianna, 1920:262), salvara a unidade nacional no Império, mas era limitada. Faltava infundir no povo o sentimento de um "alto destino histórico", o que ainda teria que ser obtido por um Estado capaz de impor-se "pelo prestígio fascinante de uma grande missão nacional" (ibidem:305).

A visão de Sergio Buarque tem muitas afinidades com a narrativa de Oliveira Vianna. O autor também partia do isolamento rural para a 
constatação de que as famílias ignoravam princípios superiores que pudessem tolher sua autonomia. Predominavam no país as vontades particularistas, próprias aos "círculos fechados e pouco acessíveis a uma ordenação impessoal" (Holanda, 1936:101). A família era o principal desses círculos, e constituía a imagem modelar de poder, respeitabilidade e obediência. No âmbito familiar, as relações fundam-se no sangue e no coração. Por isso, a "supremacia absorvente" do núcleo familiar sobre a sociedade torna desconhecida qualquer "forma de convívio que não seja ditada por uma ética de fundo emocional" (ibidem:105). Esse tipo de sociabilidade é dito cordial, pois dimana do coração. Decorria da cordialidade uma aversão às regras impessoais e coercitivas, próprias da civilidade. Os ritualismos sociais pressupõem uma medida de distanciamento entre as pessoas, contrária ao "desejo de estabelecer intimidade" que é marca registrada da cordialidade (ibidem:103).

Chega-se, nessa altura, ao que já se definiu como o cerne do projeto intelectual que animou a edição princeps de Raízes do Brasil: a definição da identidade do homem brasileiro (Wegner, 2014). De acordo com Sergio Buarque: o "horror às distâncias [...] parece constituir, ao menos até agora, o traço mais específico do espírito brasileiro" (Holanda, 1936:107). A cordialidade representaria, com efeito, "um aspecto bem definido do caráter nacional" (ibidem:101). Esse caráter é encarnado pelo "homem cordial". Vista em perspectiva comparada, a alegoria do homem cordial faz pensar imediatamente na do homo rusticus, também ele um personagem que estereotipa as características humanas próprias do meio brasileiro. Revela-se aí um componente identitário que aproxima as argumentações de Sergio Buarque e Oliveira Vianna. Ambos põem em circulação, por intermédio desses personagens desindividualizados, enunciados capazes de oferecer algum sentido de identidade nacional, embora apenas tentativamente (em Oliveira Vianna) ou provisoriamente (vide a ressalva em Sergio Buarque: "ao menos até agora").

Essas duas figuras alegóricas, que de alguma forma condensam o legado colonial, colocam-se como barreiras à implantação da ordem pública moderna no país. Sergio Buarque escolheu como epígrafe ao quinto capítulo de seu livro, intitulado "O Homem Cordial", este verso do poeta seiscentista John Milton: "uma ínfima parte do que o coração tem que aguentar é afetada pela ação dos reis ou das leis..." (apud Holanda, 1936:91). Ou seja, com Milton, a discussão sobre a cordialida- 
de fica desde logo sob o signo da desconfiança quanto à aplicabilidade das normas impessoais. Essa reticência quanto à possibilidade de que a ordem pública pudesse "causar" sentimentos virtuosos ou "curar" os viciosos era especialmente compreensível no ambiente privatista retratado por Sérgio Buarque e por Oliveira Vianna. O coração que pulsava no homem cordial pareceria poder bater também no peito do homem rústico. A vocação privatista era a mesma em ambos.

Sergio Buarque registra desafios similares aos descritos por Oliveira Vianna no tocante à implantação da ordem pública. A impressão deixada pela ordem familiar rural gerava uma forte nostalgia no homem urbano. Dava-se uma "invasão do público pelo privado, do Estado pela Família", o que explicava a "difícil adaptação" do país ao Estado democrático e a uma burocracia eficiente (Holanda, 1936:89). Sergio Buarque não relata aquela "invasão" com complacência. Em que pesem as dúvidas consignadas quanto à viabilidade de uma ordem pública no país, não se furta a afirmar categoricamente no parágrafo inicial do quinto capítulo:

\begin{abstract}
Não existe, entre o círculo familiar e o Estado, uma gradação, mas antes uma descontinuidade e até uma oposição. A indistinção entre essas duas formas é um prejuízo romântico e que teve os seus adeptos mais entusiastas e mais zelosos durante o século décimo-nono [...]. Só pela superação da ordem doméstica e familiar é que nasce o Estado (Holanda, 1936:93).
\end{abstract}

Até essa passagem, o Estado desvinculado das condições ambientes e contraposto ao círculo familiar vinha sendo pensado como uma forma de desterro, contra a qual se dirigia o peso da crítica do livro. Mas nesse ponto o ensaio alterna seu ângulo de visão, não para referendar tal e qual o desterro que vinha sendo condenado, mas para abrir uma nova perspectiva sobre a civilidade. A civilidade não é pensada somente de modo desfavorável. Ela não se reduz à democracia liberal, entendida como forma política decadente (Waizbort, 2011). Ainda que a cordialidade fosse um traço identitário, ou justamente por isso, era preciso buscar algum fundamento de estabilidade. "É necessário um elemento normativo, sólido, [...] para que possa haver cristalização social" (Holanda, 1936:156-157). Patenteia-se a tensão em que a narrativa simpática ao legado colonial, ou, simplesmente, à cordialidade, entra em choque com a necessidade de estabelecimento de algum tipo de ordem assentada na impessoalidade, ou na civilidade. 
A limitação das formas de solidariedade social ao círculo das preferências afetivas, operada pela cordialidade, tem um correlato claro na insolidariedade, em que o clã é o único vínculo realmente sentido. Embora estes conceitos tenham estatutos próprios, insolidariedade e cordialidade podem ser vistos em uma "posição de equivalência estrutural" em Raízes do Brasil e Populações Meridionais do Brasil (Gomes, 2010). Similares as causas, semelhante o efeito: também para Sergio Buarque o conceito de Estado é de difícil intelectualização.

Havendo acompanhado Oliveira Vianna tanto no diagnóstico do desterro quanto em traços básicos da enunciação do privatismo brasileiro, Sergio Buarque afasta-se da solução proposta pelo autor fluminense para o "pecado de cem anos". Pouco na discussão de Sergio Buarque evocará a "trituração" das oligarquias políticas, o pleito por um "idealismo orgânico" e a defesa da infusão no povo de um sentimento de destino nacional. (Apenas no "parlamentarismo brasileiro" haverá uma proximidade.) É no diálogo com Gilberto Freyre que se pode esclarecer o prognóstico político de Sergio Buarque, diverso e mesmo oposto ao de Oliveira Vianna.

\section{A LIÇÃO PORTUGUESA}

Gilberto Freyre tem uma presença de peso em Raízes do Brasil. O autor assina o prefácio da obra, no qual afirma ser Sergio Buarque "uma daquelas inteligências brasileiras em que melhor se exprimem não só o desejo como a capacidade de analisar, o gosto de interpretar, a alegria intelectual de esclarecer" (Freyre, 1936a:v). Sergio Buarque, de sua parte, considerava Casa-Grande \& Senzala "o estudo mais sério e mais completo sobre a formação social do Brasil" (Holanda, 1936:105). O diálogo entre ambos será ostensivo e profícuo. A partir de observações de Ricardo Benzaquen de Araújo (2000; 2005), e sem a pretensão de exaurir o tema, é possível vislumbrar os contornos da contribuição de Gilberto Freyre para a montagem da visão genética e do elogio da cordialidade contidos em Raízes do Brasil ${ }^{3}$.

O ethos da colonização portuguesa no livro de Sergio Buarque assenta-se na renúncia à ação transformadora no mundo, derivada do personalismo, e na atitude plástica de adaptação às circunstâncias da realidade, decorrente do aventureirismo. Por um lado, a cultura ibérica da personalidade predicava-se na máxima independência do indivíduo frente aos seus pares. Nessa concepção, traduzida no sentimento de so- 
branceria, o "círculo de virtudes capitais" relacionava-se diretamente com o "sentimento da própria dignidade de cada homem" (Holanda, 1936:10). Atributos como o proceder sisudo, a inteireza e o termo honrado eram "virtudes essencialmente inativas, pelas quais o indivíduo se reflete sobre si mesmo e renuncia a modificar a face do mundo" (ibidem:12). Por outro lado, a ética da aventura de que estavam imbuídos os colonizadores portugueses os predispôs a se amoldarem à realidade dos trópicos. Os primeiros colonos do Brasil "aclimavam-se facilmente, aceitando o que lhes sugeria o ambiente, sem cuidar de impor-lhe normas fixas e indeléveis" (ibidem:26-27). Um exemplo disso foi a assimilação de incontáveis costumes indígenas. Outro foi o acolhimento de dissonâncias raciais, devido, segundo Sergio Buarque, à ausência quase completa de orgulho de raça no português. Tratava-se de "face bem típica de sua extraordinária plasticidade social", explicada "muito pelo fato de serem os portugueses [...] um povo de mestiços" (ibidem:27).

A associação entre o perfil mestiço do português e a plasticidade de sua ação colonizadora leva a marca inconfundível de Casa-Grande \& Senzala. É revelador a esse respeito que, logo no quinto parágrafo de Raízes do Brasil, a Península Ibérica fosse designada como uma "região indecisa entre a Europa e a África" (Holanda, 1936:4). Pois é essa mesma imagem, aplicada unicamente a Portugal, que Gilberto Freyre emprega no terceiro parágrafo do capítulo inicial de sua obra para explicar a origem da adaptabilidade lusa ao Novo Mundo: "A singular predisposição do português para a colonização híbrida e escravocrata dos trópicos, explica-a em grande parte o seu passado étnico, ou antes cultural, de povo indefinido entre a Europa e a África" (Freyre, 1933:2). A “indecisão étnica e cultural" era responsável pela índole "flutuante" dos portugueses: "o bambo equilíbrio de antagonismos reflete-se em tudo que é seu, dando-lhe ao comportamento uma fácil e frouxa flexibilidade" (Freyre, 1933:5). Esse perfil deu aos portugueses a dianteira na colonização dos trópicos. A índole flexível criada pela mestiçagem originária os permitiu alcançar inigualada propensão à miscibilidade, mobilidade e aclimatabilidade, categorias que se condensam na de plasticidade.

A plasticidade suscita outro encontro entre interpretações em Raízes do Brasil, dessa feita com Casa-Grande \& Senzala, derivando-se naquele da ética da aventura, e neste da mestiçagem. Ao formular o ethos colonial, Sergio Buarque combinava considerações a respeito da cultura da per- 
sonalidade, próprias ao seu livro, com uma reflexão sobre o espírito da aventura que engajava a abordagem de Gilberto Freyre. A plasticidade originada na mestiçagem entre Europa e África somava-se à renúncia à modificação da realidade para criar um tipo especialmente bem-sucedido de colonizador. O desmazelo com as normas fixas, transmitido aos habitantes da nova terra, teria uma consequência direta na aversão do homem cordial à impessoalidade. Outra consequência seria o desleixo no traçado das cidades construídas no Brasil, diferentemente da urbanização planificada das colônias espanholas, e ainda aqui é possível surpreender-se o diálogo criativo de Sergio Buarque com seu estimado colega de geração.

É conhecido o argumento no quarto capítulo de Raízes do Brasil: “a cidade que os portugueses construíram na América não é produto mental, não chega a contradizer o quadro da natureza, e sua silhueta confunde-se com a linha da paisagem" (Holanda, 1936:62). Menos notada é uma passagem duas frases depois, suprimida nas edições posteriores do livro: "As casas eram semeadas com desalinho, em volta de uma igreja toda branca e situada quase sempre no lugar mais elevado; com um desalinho que faz pensar um pouco nesses jardins de Portugal evocados por Gilberto Freyre, cheios de uma poesia meio selvagem" (ibidem:62). A referência é a um artigo de opinião de Gilberto Freyre no Diário de Pernambuco de março de 1925, intitulado "Acerca de Jardins" (Freyre, 1979 [1925]), depois republicado em coletânea (Freyre, 1934). Freyre louvava o caráter irregular dos jardins de Portugal, com sua "meia selvageria que é a delícia da nossa natureza". Antepunha essa "magnífica lição portuguesa" ao "rígido geometrismo dos jardins suíços e franceses, que obrigam as flores e as plantas a atitudes de soldados em dia de parada" (ibidem:43-46).

A discussão de Gilberto Freyre sobre os desleixados jardins portugueses há de ter sido um achado para Sergio Buarque, que tira daí a bela imagem das cidades semeadas. (Apenas na segunda edição de Raízes, em 1948, surgiriam as figuras do semeador e do ladrilhador.) De alguma maneira, era a própria (des)ordem da aventura e do personalismo que se incrustava no espaço urbano brasileiro. Isso não podia deixar de contribuir para mitigar as forças impessoais que o autor sabia emanarem da "habitação em cidades, que é, essencialmente, uma habitação antinatural; associa-se a uma poderosa manifestação do espírito e da vontade, na medida em que estes se opõem à natureza" (Holanda, 1936:59). A partir do desembarque da família real, em 1808, o ímpeto 
dado à urbanização e a formas de vida mais pautadas pela civilidade começaria a pôr em relevo essa contradição. Com a Abolição, oitenta anos mais tarde, a transição entre a "ditadura dos domínios rurais" e a "urbanocracia" lançaria a sociedade brasileira em uma grave crise (ibidem:50 e 43). Por ora, cabe apenas dimensionar esse como enraizamento da cultura ibérica no país.

Herança ibérica (ou: ethos colonial), ruralismo e cordialidade andam juntos, como já se afirmou com razão (Avelino, 1990). Conforme exposto na seção anterior, a base rural da sociedade colonial criou as condições para uma profunda fragmentação, em que a sociabilidade limitava-se ao círculo familiar e a consciência pública não excedia as preferências políticas pessoais ou clânicas. Insolidariedade e cordialidade podiam ser vistas por Oliveira Vianna e Sergio Buarque como elementos negativos, por constituírem óbices à ordem moderna. Mas a cordialidade também admitiria uma visão positiva, à diferença da insolidariedade. Não apenas de estrutura social fragmentária se fazia o Brasil. O país herdara a cultura ibérica, com destaque para o personalismo e a aventura. Engastados nas fazendas e nas cidades, esses elementos participaram da moldagem do caráter nacional brasileiro. $\mathrm{O}$ ethos colonial, conjugação de renúncia à mudança da realidade com plasticidade social, gravara-se no cerne na cordialidade. Esta converte-se, assim "em uma espécie de filtro entre o homem e o mundo, filtro que impede a redução do mundo ao projeto interno do sujeito, forçando um certo tipo de negociação entre ele[s]" (Araújo, 2005:42). Na polidez, ou civilidade, pressupunha-se uma "presença soberana do indivíduo", e obtinha-se "um dos mais decisivos triunfos do espírito sobre a vida" (Holanda, 1936:102). Sob o império da cordialidade, todavia, "A vida íntima do brasileiro não é bastante coesa, nem bastante disciplinada, para envolver e dominar toda a personalidade, ajustando-a como uma peça consciente ao ambiente social" (ibidem:110). Incoeso o self, infactível a civilidade. O núcleo de vida cordial inviabilizava o triunfo das fórmulas abstratas.

A "aversão ao ritualismo social", correspondida pelo já mencionado "desejo de estabelecer intimidade", manifestava-se na dificuldade havida pelos brasileiros em manter prolongada reverência frente a um superior. As fórmulas de reverência eram admitidas desde que não excluíssem a possibilidade de convívio mais próximo. De acordo com Sergio Buarque, em passagem também excluída das edições posteriores do livro, 
A generalização do tratamento por "você", que perdeu, aliás, a tonalidade cerimoniosa e substitui, praticamente, o tratamento pela segunda pessoa, poderia ser explicado por motivos especiais: limitemo-nos a lembrar, por enquanto, que não foi, talvez, simples casualidade o que fez coincidir a extensão geográfica, entre nós, do uso dessa forma de tratamento com a parte do território brasileiro em que teve maior força a escravidão africana: o extremo norte e, sobretudo, o extremo sul utilizam-na menos do que o centro (1936:103).

Novamente, sente-se que Raízes do Brasil - e também “Corpo e Alma do Brasil", onde o trecho aparece pela primeira vez - entabula diálogo com Casa-Grande \& Senzala. O argumento de que a forma linguística é flexibilizada em função da ocorrência do regime híbrido e escravocrata de colonização remete à demonstração de uma tese central de Casa-Grande. Para Sergio Buarque, o tratamento por "você" era um índice da cordialidade. Para Gilberto Freyre, a flexibilidade no uso da próclise e da ênclise indicava o equilíbrio de antagonismos na formação brasileira:

Temos no Brasil dois modos de colocar pronomes, enquanto o português só admite um - o "modo duro e imperativo": diga-me, faça-me, espere-me. Sem desprezarmos o modo português, criamos um novo, inteiramente nosso, caracteristicamente brasileiro: me diga, me faça, me espere. Modo bom, doce, de pedido. E servimo-nos dos dois. Ora, esses dois modos antagônicos de expressão, conforme necessidade de mando ou cerimônia, por um lado, e de intimidade ou de súplica, por outra [sic], parecem-nos bem típicos das relações psicológicas que se desenvolveram através da nossa formação patriarcal entre os senhores e os escravos; [...] A força ou antes a potencialidade da cultura brasileira parece-nos residir toda na riqueza dos antagonismos equilibrados; o caso dos pronomes que sirva de exemplo [...]. Somos duas metades confraternizantes que se vêm mutuamente enriquecendo de valores e experiências diversas; quando nos completarmos num todo, não será com o sacrifício de um elemento ao outro (1933:376-377).

A proximidade entre o caso dos pronomes de tratamento e o caso da colocação pronominal é significativa. É o próprio Sergio Buarque quem traça o paralelo entre o linguajar encurtador de distâncias sociais e a zona de colonização escravocrata. Custaria a crer que ele não tivesse em mente, nessa aproximação, a tese proposta pelo prefaciador de seu livro. O paralelo entre os exemplos de uso pronominal pode ser formulado de modo mais preciso nos seguintes termos: a área onde grassa o 
tratamento por "você", típico do desejo cordial de intimidade, coincide com a área onde se fixou a variação entre uso proclítico e enclítico, típica do equilíbrio de antagonismos da colonização híbrida e escravocrata do Brasil. Cordialidade e equilíbrio de antagonismos parecem produzir efeitos similares, pelo que são suscetíveis de uma aproximação mais detalhada. Ressalve-se apenas terem estatutos diferentes, como se nota do fato de Gilberto Freyre falar em uma "necessidade" de "mando" e "intimidade", ao passo que Sergio Buarque aborda somente o "desejo" de "intimidade".

Um primeiro aspecto desse cotejo diz respeito à identificação de algum tipo de elemento nacional na cordialidade e no equilíbrio de antagonismos. Em Casa-Grande \& Senzala, a sociedade patriarcal é profundamente vincada pelo privatismo. O regime de monocultura latifundiária acompanha-se do mal inseparável do "exagerado sentimento de propriedade privada. O qual começa criando rivalidades sangrentas entre vizinhos - grandes senhores de terras - para terminar balcanizando continentes" (Freyre, 1933:386-387). Embora os habitantes da colônia compartilhassem um substrato cultural, esse quadro anárquico tornaria impossível a formação de uma unidade nacional. Sucede que as tendências dispersivas eram contrabatidas por forças homogeneizadoras de igual ordem. Com sua ação disciplinadora, oposta à experiência desregrada dos senhores de engenho, os padres jesuítas contribuíram para salvaguardar a integridade da colônia. O catolicismo, de modo mais amplo, foi "realmente o cimento da nossa unidade" (ibidem:43). A unidade não resultava somente do patriarcalismo, nem do jesuitismo ou do catolicismo, mas, algo precariamente, do equilíbrio entre essas tendências antagônicas de dispersão e uniformização. Um "todo" alcançado sem o sacrifício de uma parte a outra, e sim pela "confraternização" entre ambas. Essa dinâmica ilustra o sentido da defesa da nacionalidade feita por Gilberto Freyre, na qual "o que está efetivamente em jogo não é uma substância específica, mas aquela maneira particularmente híbrida e plástica de combinar as mais diferentes tradições sem pretender fundi-las em uma síntese completa e definitiva: antagonismos em equilíbrio" (Araújo, 2005:133).

Por esse caminho, tornava-se possível pensar a unidade - conquanto instável - em uma sociedade de outra forma balcanizada pelo privatismo. Nesse sentido, a aproximação da cordialidade ao equilíbrio de antagonismos se terá afigurado a Sergio Buarque como particularmente proveitosa. Compartilhando com Oliveira Vianna a narrativa sobre a 
baixa coesão social, podia não obstante conceber, com Gilberto Freyre, uma escala nacional no Brasil. Nisto o porquê da visão positiva do passado nacional que se encontra em Casa-Grande E Senzala, sem paralelo em Populações Meridionais do Brasil: a colônia legara ao país uma unidade nacional (Ricupero, 2010). Em Raízes do Brasil, a visão positiva da herança portuguesa e colonial também não deixa margem a dúvidas. Algumas de suas passagens mais contundentes dirigem-se àqueles que pretendiam negar a "alma comum" com a Península Ibérica. A "tradição longa e viva", lia-se no primeiro capítulo, era uma verdade indubitável, "por menos sedutora que possa parecer [a] alguns de nossos patriotas" (Holanda, 1936:15). Na nota de rodapé dedicada a Oliveira Vianna, a tese do centrifugismo era considerada "tão própria para lisonjear a vaidade patriótica de numerosos brasileiros" (ibidem:166).

A insistência nessa crítica não estava desligada do fato de que, a julgar pelo testemunho de outro importante ensaísta da época, Azevedo Amaral, a visão genética era minoritária nos meios intelectuais brasileiros de então (Amaral, 1935:75). Afirmar o papel da herança ibérica requeria uma atitude de enfrentamento. Mas se era possível tratar o patriotismo situacional como vaidade ignorante do país, por outra parte era preciso comedimento na afirmação de um caráter nacional, ponto delicado em uma explicação genética. Tudo estava em ressaltar a dimensão cultural compartilhada com terras de além-mar. Como já ficara claro em Casa-Grande \& Senzala, a peculiaridade do brasileiro devia resultar de diferenciação incremental. O equilíbrio de antagonismos já era uma característica da psicologia do português, que depois admitiria contornos próprios na experiência tropical e daria sentido à cultura brasileira. A cordialidade, por sua vez, surgiria das condições específicas de personalismo, aventura e ruralismo no Brasil. A coincidência entre a zona de colonização escravocrata e o emprego do pronome de tratamento "você" volta à tona. Segundo Sergio Buarque, esse linguajar cordial, capaz de estabelecer "um convívio mais familiar" em detrimento das hierarquias sociais (Holanda, 1936:103), não tinha correspondente em Portugal: "E isso é tanto mais específico, quanto é sabido o apego dos portugueses, tão próximos de nós, sob tantos aspectos, aos títulos e sinais de reverência" (idem). É significativo que esse esclarecimento se localize nas páginas em que a cordialidade é definida.

Um segundo aspecto da aproximação entre equilíbrio de antagonismos e cordialidade diz respeito ao significado atribuído ao caráter na- 
cional. Já se viu que a unidade nacional em Gilberto Freyre é uma totalidade tensa e instável. Quiçá, em atenção a essa maneira híbrida e plástica de conceber o nacional, as inscrições propriamente essencialistas de Sergio Buarque acerca do caráter nacional serão esparsas. Mas a passagem em que a cordialidade é definida pela primeira vez em Raí$z e s$ do Brasil é marcada pelo entusiasmo. Esse entusiasmo parecia incorporar um ponto de vista estrangeiro que busca um sentido nacional estável para categorizar o país. Em Gilberto Freyre, esse ângulo também fora contemplado, em observação acerca do equilíbrio de antagonismos: "Talvez em parte alguma se esteja verificando com igual liberalidade o encontro, a intercomunicação e até a fusão harmoniosa de tradições diversas, ou antes antagônicas, de cultura como no Brasil" (Freyre, 1933:81). Em Sergio Buarque essa ótica revela-se na menção à visita de estrangeiros:

O escritor Ribeiro Couto teve uma expressão feliz, quando disse que a contribuição brasileira para a civilização será de cordialidade - daremos ao mundo o "homem cordial". A lhaneza no trato, a hospitalidade, a generosidade, virtudes tão gabadas pelos estrangeiros que nos visitam, formam aspecto bem definido do caráter nacional. Seria engano supor que, no caso brasileiro, essas virtudes possam significar "boas maneiras", civilidade. São antes de tudo expressões legítimas de um fundo emocional extremamente rico e transbordante (Holanda, 1936:101).

O tom da passagem faz eco ao do texto, publicado em 1931 na Revista do Brasil, em que o Rui Ribeiro Couto cogitou desse personagem. O “homem cordial", dizia Couto, era um produto da junção do homem ibérico à gente e às terras do meio americano. Sua atitude de hospitalidade e credulidade era tipicamente ibero-americana, de "disponibilidade sentimental" (Couto, 2006:398). Diferenciava-se, nisto, do egoísmo fomentado na Europa pelas intolerâncias religiosas e pelas calamidades econômicas. A "civilização cordial" seria nada menos que uma "contribuição da América Latina ao mundo" (idem).

Recém-chegado de sua estada na Alemanha, Sergio Buarque deverá ter encontrado no pequeno texto de Ribeiro Couto uma intuição fundamental. A estrutura social brasileira era sem dúvida fragmentária e infensa à ordenação pública, como sentenciava Oliveira Vianna. Mas a "ética de fundo emocional" formada no recesso do mundo rural e enriquecida pela cultura ibérica tinha a capacidade de singularizar o Brasil no mundo. O cotejo com a ordem fria e impessoal da Europa desperta- 
va franco otimismo, que retoma a tonalidade benévola do parágrafo de abertura do livro: "vivemos uma experiência sem símile". Essa expressão consta da segunda frase do parágrafo, na qual também se observava que o território brasileiro poderia abrigar uma população semelhante à de todo o planeta caso fosse "povoado com a mesma densidade da Bélgica". Essa conjectura fora retirada, se bem que sem indicação da referência bibliográfica (Rocha, 2004), do célebre Porque me Ufano do Meu País, do Conde Affonso Celso. No famoso livro, postulava-se a grandeza territorial como primeiro motivo para a superioridade do Brasil. Entre outros dados, o autor citava o de que o país é trezentas vezes maior do que a Bélgica, para arrematar: “O Brasil é um mundo. Quer isto dizer que, se a população do Brasil igualar a densidade da população belga, tornar-se-á superior à que se calcula existir hoje na terra inteira" (Celso, 1901:6). É interessante que Sergio Buarque fizesse essa referência velada, justamente no incipit de Raízes do Brasil, ao expoente maior, e já estigmatizado, do tipo de "vaidade patriótica" que criticava duramente em seu próprio livro.

A explicação para o entusiasmo passa pela percepção de que havia na cordialidade - como também no equilíbrio de antagonismos - a identificação de uma "resposta criadora do modernismo à problemática de autolegitimação cultural do Brasil" (Merquior, 1981:274). Para Gilberto Freyre, ali estaria a "força ou antes a potencialidade da cultura brasileira". Para Sergio Buarque, era da "contribuição brasileira para a civilização" que se tratava. Percebe-se então porque o "tipo de cultura que representamos", citado na última frase do parágrafo inicial de seu livro, se anunciava logo no parágrafo seguinte como um "tipo próprio de cultura" (Holanda, 1936:3). Tanto a cordialidade quanto o equilíbrio de antagonismos envolviam uma grande medida de tradição lusa e outra, menor, de diferenciação brasílica. Acima de tudo, ambas apontavam para uma alternativa aos rigores da modernidade ocidental. O desejo de intimidade e a confraternização entre opostos eram, cada um à sua maneira, manifestações "daquele calor que, mal ou bem, emanava da nossa promíscua e anárquica experiência colonial" (Araújo, 2005:181). Celebrar esse calor humano não era reproduzir a apologia formalista da pátria, mas, ao contrário, exaltar a fonte de vitalidade cultural brasileira. O elogio da cordialidade estava longe do ufanismo estéril, evocado pela citação porventura irreverente do Conde Affonso Celso. Mais instigante era a frase "O Brasil é um mundo", do mesmo autor, que antecedia a observação citada sobre a Bélgica e que pode ser relida aqui no registro um tanto altíssono do 
Brasil como território capaz de abrigar uma experiência própria de modernização.

\section{UMA TRADIÇÃO ORTODOXA}

Após dimensionar o privatismo, elogiar a cordialidade e diagnosticar o desterro, Raízes do Brasil passa a se ocupar de um prognóstico político. Seria difícil abordá-lo sem fazer menção, ainda que sumária, à reflexão modernista de Sergio Buarque nos anos 1920. Um dos temas fundamentais que ela ajudaria a enquadrar em meados da década seguinte é a crítica à pretensão de que soluções jurídico-institucionais dessem conta da complexa realidade brasileira. A desconfiança em relação às fórmulas sedimentadas estava no centro do projeto modernista que buscava o desrecalque de forças inconscientes como caminho vitalista para a renovação cultural (Avelino, 1987). Em "Perspectivas", artigo publicado em 1925 na revista Estética, Sergio Buarque equiparava a linguagem a uma força de "negação de vida": "Nada do que vive se exprime impunemente em vocábulos" (Holanda, 1996b:214). Um tratado de história da civilização ainda poderia ser escrito, dizia, "em que se considera o esplendor e a decadência de cada povo coincidindo precisamente com a maior ou menor consideração que a palavra escrita ou falada mereceu de cada povo" (idem). Essa crítica continha não apenas a condenação de ímpetos negadores da realidade nacional como também uma advertência sobre a corrupção das energias do povo que insistisse em ilusões formalistas.

No artigo "O Lado Oposto e Outros Lados", saído na Revista do Brasil em 1926, o autor ironizava os passadistas que lamentavam não ser o Brasil "um país velho e cheio de heranças", ao mesmo tempo em que criticava colegas modernistas adeptos de uma "panaceia abominável da construção" (Holanda, 1996a:226-227). A arte brasileira haveria de surgir antes pela "indiferença" que pela imposição de critérios estrangeiros. Era equivocada a ideia de que o panorama artístico se definisse pela desordem: "a ordem perturbada entre nós não é decerto, não pode ser a nossa ordem; há de ser uma coisa fictícia e estranha a nós, uma lei morta, que importamos, senão do outro mundo, pelo menos do Velho Mundo" (idem:226). Os artigos de 1925 e 1926 ainda não falavam propriamente de política, mas já deixam entrever os fundamentos do esquema analítico de Raízes do Brasil. “Tudo se passa como se um núcleo de vida resistisse, e devesse resistir sempre, às construções especiosas dos homens. Aí estão, numa primeira e fundamental manifestação, as 
traves dos argumentos [de] [...] Raízes do Brasil" (Monteiro, 2012:202). Esse núcleo seria denominado o "mundo de essências mais íntimas" (Holanda, 1936:161).

Nesses termos, o prognóstico do problema do desterro em Sergio Buarque começava a tomar forma como uma cobrança de que as forças políticas emanadas desse mundo fossem libertadas: "nosso aparelhamento político [...] se empenha em desarmar todas as expressões genuínas e menos harmônicas de nossa sociedade, em negar toda espontaneidade nacional" (ibidem:144). O "pecado original" da atitude livresca fora criar um ambiente em que, como se lê no sexto capítulo de Raízes do Brasil, "nossa vida verdadeira morria de asfixia" (ibidem:126). Uma passagem em especial articula de forma consistente os temas discutidos até aqui:

Comparsas desatentos do mundo que habitávamos, quisemos viver fervorosamente contra nós mesmos, viver pelo espírito e não pelo sangue. Como Plotino de Alexandria, que sentia vergonha do próprio corpo, acabaríamos por esquecer tudo quanto fizesse pensar em nossa própria riqueza emocional, a única força criadora que ainda nos restava, para nos submetermos à palavra escrita, à retórica, à gramática, ao Direito abstrato (idem).

Aí está a crítica à negação formalista da realidade, expressa na oposição entre espírito ("palavra escrita") e vida ("sangue"), bem como a referência à cordialidade ("riqueza emocional") como elemento criador. É com a herança ibérica e a cordialidade em mente que se pode ler este trecho, no primeiro capítulo de Raízes, que retoma a problemática dos artigos da década anterior: "toda cultura só absorve, assimila e elabora verdadeiramente os traços de outras culturas, quando estes encontram uma possibilidade de ajuste aos seus quadros de vida" (ibidem:15). A crítica às importações doutrinárias combinava-se, dessa maneira, com a lógica da evolução orgânica da sociedade (Eugênio, 2011). A superação do desterro envolveria duas componentes. Por um lado, o Estado devia aceitar (em vez de negar) as forças vitais da sociedade e robustecer-se com elas; por outro, as ideias estrangeiras deviam poder ajustar-se aos "quadros de vida" brasileiros.

A experiência do Império e da República constituía, em Raízes do Brasil, o campo sobre o qual se podia refletir acerca dessa solução. No século de vida independente, a atitude livresca fora comum ao espectro político, de D. Pedro II aos positivistas. Os conselhos desses homens predicavam-se na duvidosa perspectiva de que se pudesse criar "um quadro 
social milagrosamente destacado de nossas tradições portuguesas e mestiças. O prestígio moderno e provavelmente efêmero das superstições liberais e protestantes parece-lhes definitivo, eterno, indiscutível e universal" (Holanda, 1936:128). D. Pedro II era destacado como caso exemplar do "amor bizantino pelos livros" (ibidem:126), que, no fundo, traduzia um "invencível desencanto de nossa realidade e de nossa tradição" (ibidem:130).

Sergio Buarque parece encampar, nesse momento, uma crítica de Gilberto Freyre ao bovarismo de D. Pedro II: "Esse Imperador, que alguém comparou finamente a um pastor protestante oficiando em templo católico [...]" (ibidem:127). A referência é direta a uma conferência de Gilberto Freyre por ocasião do centenário de nascimento do imperador, em 1925. O texto, publicado na Revista do Norte no ano seguinte, criticava D. Pedro II por ter assentado o governo do país nas bases equívocas da imitação dos mores da Inglaterra vitoriana e da importação do liberalismo. Contra o pano de fundo da colônia, associada ao desregramento, o Império aparecia como um tempo de cerceamento moral e político. "Olhando-se hoje o Segundo Império tem-se uma grande impressão de cinzento [...]. O liberalismo a quase todos acinzenta numa conciliação acaciana bem ao sabor do século" (Freyre, 1926:18). Fiado na "superstição da solução jurídica e do liberalismo" (ibidem:16, grifos suprimidos), o imperador afastou-se das forças em que se deveria ter escorado. Seria de desejar que D. Pedro II houvesse sido "mais sensível à aliança do Trono com a Igreja e o Exército e a Terra - os grandes senhores de engenho [...] desta rústica nobreza o Imperador poderia ter feito uma das forças do Trono" (ibidem:15). Para esse lado deveria ter pendido o poder moderador.

Em vez disso, D. Pedro II sofreu de uma "espécie de calvinismo políti-

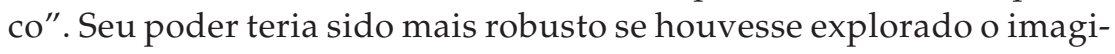
nário religioso popular:

Pedro II [...] exagerou-se na tirania moral para falhar na estética ou ri-
tual do Poder - elemento tão caro ao sentido de beleza de um povo nas-
cido sob o encanto da liturgia da missa [...]. E à testa da monarquia bra-
sileira, igreja manuelina a pedir missas pontificais, ele nos dá esta ideia
melancólica: a de um pastor protestante a oficiar em catedral católica
(ibidem:12-13).

A analogia religiosa ganha mais densidade com o entendimento de catolicismo com que trabalhava Freyre. Uma virtude da Igreja era "a de 
manter intactas, sem as confundir, energias divergentes, tragicamente divergentes até, como o culto da família e o culto da virgindade. O vermelho e o branco" (ibidem:19). Embora o conceito só fosse ser delineado com clareza alguns anos mais tarde em Casa-Grande E Senzala, indicava-se que D. Pedro II poderia ter governado mais "brasileiramente" (ibidem:17), com mais cor e menos cinza, por meio do equilíbrio de antagonismos herdado da colônia. O certo é que Gilberto Freyre evocava no fim da conferência alguns luminares do patriarcalismo político do Segundo Reinado, cujas "vozes ortodoxas perdidas no coro da oratória liberal [...] são vozes a reviver hoje, [...] para que se fixe mais inteligentemente uma tradição ortodoxa entre nós" (ibidem:22).

Tomando de empréstimo a Gilberto Freyre a imagem do pastor protestante oficiando em catedral católica, e talvez também a expressão das superstições liberais e protestantes, Sergio Buarque não o acompanhava na avaliação do Segundo Reinado. O "bovarismo nacional" de fato marcara o Império, mas a verdade é que se agravara na República: "o mal [...] cresceu com o tempo [...] nesse ponto, a nossa república ainda foi além da monarquia" (Holanda, 1936:130). No Império, uma doutrina política estrangeira fora ajustada aos quadros de vida brasileiros e o Estado retirara deles sua força:

Neste o princípio do Poder Moderador, chave de toda a organização política, e aplicação da ideia do pouvoir neutre, em que Benjamin Constant, o suíço, definia a verdadeira posição do chefe de Estado constitucional, corrompeu-se bem cedo, graças à inexperiência do povo, servindo de base para a nossa monarquia tutelar, bem compreensível em um regime agrário e patriarcal. A divisão política, segundo o modelo inglês, em dois partidos menos representativos de ideologias do que de personalidades e de famílias, satisfazia nossa necessidade fundamental de solidariedade e de luta. Finalmente o próprio parlamento tinha uma função precípua a cumprir dentro do quadro da vida nacional, dando uma imagem visível dessa solidariedade e dessa luta (idem:131).

Sergio Buarque referia-se nessa passagem ao personalismo. $\mathrm{O}$ culto exaltado à independência pessoal traduzia-se, no plano político, em um obstáculo à estabilidade e à solidariedade. Lê-se no começo de Raízes do Brasil que a anarquia encontrava no país um campo fértil, e cúmplices nas instituições e costumes. "Em terra onde todos são barões, não é possível acordo coletivo durável, a não ser por uma força exterior respeitável e temida" (idem:5). Nos países ibéricos, isso redundou mui- 
tas vezes em ditaduras militares. Mas Sergio Buarque formula uma ressalva para o caso brasileiro. "Entre nós", dizia, a força não poderia ser despótica, pois se incompatibilizaria com a cordialidade: "o despotismo condiz mal com a doçura de nosso gênio" (idem:142). O Estado necessitava, sim, de "pujança", "compostura", "grandeza" e "solicitu$\mathrm{de}^{\prime}$ ", meios para que adquirisse "alguma força e também essa respeitabilidade que os nossos pais ibéricos nos ensinaram a considerar como a virtude suprema entre todas" (idem). O Império encarnara esse ideal, e por isso fixara-se na imaginação coletiva.

Note-se como o autor detalha em três pontos o ajuste entre o regime político e o substrato cordial e personalista. Em primeiro lugar, o poder moderador embasara a monarquia tutelar, "bem compreensível" no regime agrário e patriarcal. (Registre-se que, na segunda edição do livro, o advérbio "bem" seria suprimido, tornando a linguagem menos apologética da forma monárquica.) Em segundo lugar, o bipartidarismo exprimia adequadamente da "necessidade fundamental" de conflito e colaboração típica de uma sociedade composta por indivíduos sobranceiros. Em terceiro lugar, o parlamentarismo cumpria a função de dar uma "imagem visível" da dinâmica política personalista. Bem compreendido, isto é, equacionado com respeito à cordialidade, o personalismo tornava-se "uma noção positiva", ao lado da qual sobressaía o aspecto "decorativo" dos lemas da democracia liberal. Daí porque o personalismo, nos países latino-americanos em que afastara as resistências liberais, "tenha assegurado [...] uma estabilidade política que de outro modo não teria sido possível. A formação de elites de governantes em torno de personalidades prestigiosas tem sido, ao menos por enquanto, o princípio político mais fecundo em nossa América" (idem:152).

Sergio Buarque apontava no Império um regime político exitosamente articulado com a base da sociedade. Ora, era precisamente essa a cobrança que Gilberto Freyre dirigira a D. Pedro II. Onde o pernambucano vira um fracasso, o paulista vira um sucesso. É como se a "tradição ortodoxa" ligada ao equilíbrio de antagonismos, que Gilberto Freyre propusera fosse revivida, houvesse sido surpreendida em plena atividade por Sergio Buarque. A "monarquia tutelar" e o "regime agrário e patriarcal" associavam-se com a força da aliança que Freyre desejava ter existido entre o "Trono" e a "Terra". No artigo "Corpo e Alma do Brasil", de 1935, havia uma ressalva a esse respeito, retirada em Raízes do Brasil: “Não quer dizer que o Império representasse em todos os sen- 
tidos uma forma definitiva, ou sequer o gérmen de um sistema orgânico com o substractum da nacionalidade. É indiscutível, porém, que estava menos longe disso que a República" (Holanda, 2006:420). Sergio Buarque julgava o Segundo Reinado por um olhar mais benévolo, talvez um vestígio de seu monarquismo de juventude (Eugênio, 2008).

A interpretação que Sergio Buarque faz do século XIX difere em importantes aspectos daquelas propostas por Oliveira Vianna e por Gilberto Freyre, embora dialogue com ambas. O autor está mais próximo de Freyre do ponto de vista da prescrição de um enlace do Estado à base social e cultural do país, mas não deixa de observar que a indistinção entre as ordens familiar e pública era "prejuízo romântico". Para mais, distancia-se de Freyre ao considerar que a doutrina liberal foi devidamente absorvida, ou esterilizada, pelo personalismo e pela cordialidade. Remontava, nesse ponto, ao entendimento de Oliveira Vianna acerca da prevalência do "clanismo" sobre o "quixotismo". O desacordo entre aspirações políticas e condições sociais resolvia-se em favor destas. Já o acinzentamento que Freyre apontava no liberalismo do Segundo Reinado em sua conferência de 1925 equivalia à supressão do desregramento social colonial. Esse abafamento daria a deixa, em Sobradose Mucambos, para a denúncia do reordenamento quase total da sociedade brasileira em função de uma modernização excludente e estetizante (Araújo, 2000). Basta recordar a exclusão dos escravos das senzalas para os longínquos mucambos, e a estetização embutida nos jardins de canteiros geométricos.

Com Oliveira Vianna, Sergio Buarque comunga a avaliação de que a ordem política do Segundo Reinado baseou-se em um ajuste da doutrina às condições locais. Para Populações Meridionais do Brasil, tratara-se de "inegável hipocrisia"; para Raízes do Brasil, a inexperiência popular ensejara uma "corrupção". Para Sergio Buarque, o sentido do ajuste era a acomodação às condições personalistas e cordiais. Em se tratando do século XIX, Sergio Buarque aparentava dar-se por satisfeito com um quadro político personalista que resguardasse a cordialidade. Para Oliveira Vianna, o ajuste era uma burla da burla, ou seja, uma forma de neutralizar a ilusão liberal e fortalecer o poder central em sua "trituração" dos clãs políticos de formação imemorial.

A urbanização alterará completamente o equilíbrio alcançado no Segundo Reinado. As inovações materiais haviam sido introduzidas no país até então de modo congruente com a "estrutura moral" em vigor e 
com o "predomínio da casta dos senhores rurais" (Holanda, 1936:45). O limite dos empreendimentos econômicos era dado pelo critério de que não "alterassem profundamente a fisionomia" do país (idem:46). Quando isso de fato ocorreu, com a Abolição, o colapso do ruralismo levaria consigo o iberismo. O "aniquilamento das raízes ibéricas" da cultura brasileira era um "lento cataclismo", e ainda não estava bem delineado o "americanismo" que tomaria seu lugar (idem:137). Mas as reflexões de Gilberto Freyre e de Oliveira Vianna teriam pouca valia para Sergio Buarque na busca do caminho a seguir. Os projetos desses dois autores não suscitam proximidades tão relevantes, seja na chave da recuperação do equilíbrio de antagonismos (Freyre, 1936b), seja na chave da organização de um aparato estatal corporativo, que aparece na obra de Oliveira Vianna já antes da publicação de Raízes do Brasil (Vianna, 1930).

$\mathrm{O}$ retorno à ordem personalista, identificada em bom funcionamento no Segundo Reinado, não era mais possível. "Hoje a obediência como princípio de disciplina parece uma forma caduca e impraticável, e daí sobretudo a instabilidade constante de nossa vida social" (Holanda, 1936:15). Para se fundamentar, a respeitabilidade do Estado teria que buscar elementos estranhos ao "círculo de virtudes capitais" da gente ibérica. O personalismo podia ser o principal ameaçado com o debacle da cultura ibérica, mas a cordialidade tampouco oferecia terreno seguro. Uma alternação final do ângulo de avaliação do ensaio colocava o elogio da cordialidade sob o signo da dúvida: "Com a cordialidade, a bondade, não se criam os bons princípios" (idem:156). O personalismo, sozinho, não era mais suficiente para gerar ordem, e não bastava tampouco depender da cordialidade. Alguma medida de civilidade tornava-se indispensável, preservado o núcleo de vida cordial. Parecia improvável encontrar esse elemento normativo "inato na alma do povo" (idem), que se vê ser justamente a cordialidade. Restava examinar a viabilidade das tiranias, da oligarquia ou da democracia, mas essa era outra questão, que Sergio Buarque enfrentaria pelo diálogo com outros autores. O autor concluía afirmando que cordialidade e civilidade deviam fazer um contraponto para que algum tipo de estabilidade pudesse ser alcançado. Em 1926, a "nossa ordem" era um elemento fictício e estrangeiro, próximo ao campo semântico da decadência civilizacional. Em 1936, ela era substituída pela "nossa desordem", a cordialidade, "força criadora" capaz de levar a um "tipo próprio de cultura" e de renovar os destinos nacionais. Seria preciso organizá-la sem destruí-la: "ensaiar a organização de nossa desordem". 


\section{CONCLUSÃO}

Concatenar as partes da primeira edição de Raízes do Brasil não é tarefa simples, e menos ainda extrair de sua leitura uma conclusão unívoca. À maneira ensaística, o autor alterna o ângulo de avaliação sobre a cordialidade. Ela é, a um tempo, vista como séria barreira à implantação da ordem pública e celebrada como principal distinção do caráter nacional brasileiro. A ambiguidade seria eliminada, ou reduzida, nas edições posteriores da obra, prevalecendo sua avaliação como obstáculo. Essa intervenção no texto desacostumaria o público leitor à ideia de Raízes do Brasil como um livro que trata de modo largamente benévolo a herança colonial, e de seu autor como um intelectual disposto a reconhecer e até a promover o papel da tradição no equacionamento do dilema nacional brasileiro. Daí, por exemplo, a definição de Sergio Buarque como um "inimigo do passado" (Carvalho, 1993), a identificação de uma linha "sempre antitradicionalista" em seus livros (Barbosa, 1988), a equiparação da cordialidade a "grilhões do passado" (Lamounier, 2006) e a contextualização de Raízes do Brasil como uma provocativa "denúncia" das raízes ibéricas "na antessala do Estado Novo" (Costa, 2011). A fixação do argumento do livro como, desde sempre, um pleito pela ruptura com a tradição tem a consequência adicional de atribuir retrospectivamente ao jovem Sergio Buarque o patronato de certa linhagem do pensamento político e social brasileiro, além levar à errônea indicação de 1936 como um marco no debate entre as correntes americanista e iberista no Brasil (cf. Werneck Vianna e Perlatto, 2011). Independentemente da exatidão com que essas caracterizações se apliquem às edições posteriores de Raízes, o fato é que quadram mal com o círculo de preocupações do autor naquele ano.

O exame dos diálogos de Sergio Buarque com Oliveira Vianna e com Gilberto Freyre ajuda a iluminar a oscilação no tratamento da cordialidade. Há encontros de interpretações em pontos importantes. Com Oliveira Vianna, o autor compartilhava a visão negativa da cordialidade (ou insolidarismo) como barreira à implantação do espaço público, e o diagnóstico dos efeitos negativos da importação de doutrinas políticas desajustadas à realidade nacional. Diferiam nisto que um pugnava pela transformação dessa realidade pela ação decidida de um Estado imbuído de uma missão nacional, ao passo que o outro defendia a preservação do núcleo de vida cordial. Com Gilberto Freyre, Sergio Buarque compartilhava a visão positiva da cordialidade (aproximadamente, o equilíbrio de antagonismos) como contribuição brasileira ao 
mundo. O Brasil oferecia uma alternativa tropical e calorosa a uma modernização que conduzia alhures ao egoísmo e ao resfriamento das relações sociais. Um e outro também viam favoravelmente a impregnação do Estado pelo substrato cultural da sociedade brasileira. Isso tendia a aproximar o prognóstico do desterro de Sergio Buarque ao de Gilberto Freyre, mas Sergio Buarque se diferenciaria por considerar que a revivescência do passado não constituía por si só caminho suficiente para resolver o impasse político que descrevera.

A edição princeps de Raízes do Brasil inicia-se com uma cifra e conclui-se com um contraponto. Seu parágrafo de abertura traça os contornos de um dilema cuja solução só se indica imprecisamente no parágrafo de encerramento. O dilema compõe-se pela enunciação de um núcleo de vida que deve ser preservado, até porque legitima o Brasil como nação, mas que requer o complemento de alguma forma de normatividade que viabilize a vida política nacional. O desterro foi o resultado de tentativas malogradas de suprimir, ou sublimar, a cordialidade na busca da estabilização política. Aceitar o país como ele é exige abjurar crenças desterradas, que implicam em reduzir, negando-a, a desordem à ordem. Bem posto, o problema era organizar a desordem. Esse oximoro era o modo adequado de formular a questão e de começar a apontar o modo de equacioná-la. A solução passava pela correção dos excessos da cordialidade pela civilidade. As ordens familiar e pública deviam ajustar-se em um contraponto. Com esse fecho, cujo estudo mais detido é matéria para outro artigo, o livro interpelava a realidade nacional e dois de seus maiores intérpretes em seus próprios termos. Desprovido, é verdade, da defesa da democracia que depois o notabilizou, a pregnância de sua mensagem era, todavia, indiscutível. Isso basta para sugerir que, no momento em que ganham fôlego as arqueologias de seu texto original, o status de Raízes do Brasil como um clássico pode começar a ser pensado não só pelo lado canônico, como também por outros lados.

(Recebido para publicação em outubro de 2014) (Aprovado para publicação em fevereiro de 2015) 


\section{NOTAS}

1. A ortografia de todos os trechos citados dessa e de outras obras foi atualizada.

2. Segundo José Murilo de Carvalho (1993), a ruptura seria apenas aparente, pois a solução do problema da insolidariedade seria buscada por um Estado impregnado por valores ibéricos. Luiz Werneck Vianna (1993) sustenta tese afim. Sem entrar no mérito da questão, consigne-se simplesmente que este artigo adota, para o período estudado da obra do autor, um entendimento mais próximo da visão de Wanderley Guilherme dos Santos, de acordo com a qual, para Oliveira Vianna, "o Brasil precisa de um sistema político autoritário cujo programa econômico e político seja capaz de demolir as condições que impedem o sistema social de se transformar em liberal. Em outras palavras, seria necessário um sistema político autoritário para que se pudesse construir uma sociedade liberal" (Santos, 1978:93, ênfase suprimida).

3. Não se desconhecem as objeções à noção de cultura tal como empregada por Gilberto Freyre (Lima, 1989). Considera-se todavia que, apesar de suas inconsistências, Casa-Grande \& Senzala ajudou Sergio Buarque a imaginar um legado cultural peninsular permeando a sociedade brasileira. 


\section{Luiz Feldman}

\section{REFERÊNCIAS BIBLIOGRÁFICAS}

AMARAL, Antônio J. de A. (1935), A Aventura Política do Brasil. Rio de Janeiro, José Olympio Editora.

ARAÚJO, Ricardo B. de. (2005), Guerra e Paz: Casa-Grande \& Senzala e a Obra de Gilberto Freyre nos Anos 30. (2a ed.). São Paulo, Editora 34.

. (2000), "Sobrados e Mucambos e Raízes do Brasil", in M. C. T. de Miranda (org.), Que Somos Nós?: 60 Anos de Sobrados e Mucambos. Recife, Fundação Joaquim Nabuco, Editora Massangana, Núcleo de Estudos Freyrianos, pp. 35-46.

AVELINO FILHO, George. (1987), “As Raízes de Raízes do Brasil”. Novos Estudos, no 18, pp. 33-41.

. (1990), "Cordialidade e Civilidade em Raízes do Brasil". Revista Brasileira de Ciências Sociais, vol. 12, no 5, pp. 5-15.

BARBOSA, Francisco de A. (1988), “Verdes Anos de Sérgio Buarque de Holanda. Ensaio sobre sua Formação Intelectual até Raízes do Brasil", in s / a., Sérgio Buarque de Holanda: Vida e Obra. São Paulo, Secretaria de Estado da Cultura, Arquivo do Estado, Universidade de São Paulo, Instituto de Estudos Brasileiros, pp. 27-54.

BASTOS, Élide R. (2005), “Raízes do Brasil - Sobrados e Mucambos: Um Diálogo”. Perspectivas, vol. 28, pp. 19-36.

BITTENCOURT, André V. (2011), O Brasil e suas Diferenças: Uma Leitura Genética de Populações Meridionais do Brasil. São Paulo, Hucitec.

BRASIL JR., Antônio; BOTELHO, André. (2010), “Próximo Distante: Rural e Urbano em Populações Meridionais e Raízes do Brasil", in G. N. Ferreira; A. Botelho (orgs.), Revisão do Pensamento Conservador: Ideias e Política no Brasil. São Paulo, Hucitec, pp. 233-273.

CARVALHO, José Murilo de. (1993), "A Utopia de Oliveira Vianna”, in E. R. Bastos; J. Q. Moraes (orgs.), O Pensamento de Oliveira Vianna. Campinas, Editora da Unicamp, pp. 13-42.

(2002), "Introdução", in S. Santiago (org.), Intérpretes do Brasil. Rio de Janeiro, Nova Aguilar, pp. 899-917.

CELSO, Affonso. (1901), Porque me Ufano do Meu País: Right or Wrong, my Country. Rio de Janeiro, Laemmert \& C. Editores.

COSTA, Marcos (org.). (2011), "Apresentação", in S. B. de Holanda, Escritos Coligidos: Livro I, 1920-1949. São Paulo, Editora da Unesp/Fundação Perseu Abramo, vol. 1, pp. xi-xxxii.

COUTO, Rui R. (2006) [1931], “El Hombre Cordial, Producto Americano", in R. B. de Araújo; L. M. Schwarcz (orgs.), S. B. de Holanda, Raízes do Brasil. São Paulo, Companhia das Letras, pp. 397-398.

EUGÊNIO, João K. (2008), “Um Horizonte de Autenticidade”, in P. M. Monteiro; J. K. Eugênio (orgs.), Sérgio Buarque de Holanda: Perspectivas. Campinas, Editora da Unicamp, pp. 425-459.

. (2011), Ritmo Espontâneo: Organicismo em Raízes do Brasil de Sérgio Buarque de Holanda. Teresina, EDUFPI. 
FELDMAN, Luiz. (2013), “Um Clássico por Amadurecimento: Raízes do Brasil”. Revista Brasileira de Ciências Sociais, vol. 28, no 82, pp. 119-140.

FERREIRA, Gabriela N. (1996), "A Formação Nacional em Buarque, Freyre e Vianna". Lua Nova, vol. 37, pp. 229-247.

FRANZINI, Fábio. (2010), À Sombra das Palmeiras: A Coleção Documentos Brasileiros e as Transformações da Historiografia Nacional (1936-1959). Rio de Janeiro, Casa de Rui Barbosa.

FREYRE, Gilberto. (1926), “A Propósito de Dom Pedro II”. Revista do Norte, fase 2ạ, no 1, pp. 5-23.

. (1933), Casa-Grande E Senzala: Formação da Família Brasileira sob o Regime de Economia Patriarcal. Rio de Janeiro, Maia \& Schmidt Ltda.

. (1934), Artigos de Jornal. Recife, Edições Mozart.

. (1936a), "Prefácio", in S. B. de Holanda, Raízes do Brasil. Rio de Janeiro, José Olympio.

. (1936b), Sobrados e Mucambos: Decadência do Patriarcado Rural no Brasil. São Paulo, Companhia Editora Nacional.

. (1979) [1925], "Acerca de Jardins", in Tempo de Aprendiz. São Paulo, Ibrasa, vol. 2, pp. 154-157.

GOMES, Angela M. de C. (2010), “A Experiência Colonial e as Raízes do Pensamento Social Brasileiro: Oliveira Vianna e Sérgio Buarque de Holanda". Revista Portuguesa de História, vol. 41, pp. 291-304.

HOLANDA, Sergio B. de. (1936), Raízes do Brasil. Rio de Janeiro, José Olympio Editora.

. (1979), Tentativas de Mitologia. São Paulo, Perspectiva.

. (1996a) [1926], “O Lado Oposto e outros Lados”, in A. A. Prado (org.). S. B. de Holanda, O Espírito e a Letra: Estudos de Crítica Literária. São Paulo, Companhia das Letras, vol. 1, pp. 224-228.

. (1996b) [1925], “Perspectivas”, in A. A. Prado (org.), S. B. de Holanda, O Espírito e a Letra: Estudos de Crítica Literária. São Paulo, Companhia das Letras, vol. 1, pp. 214-218.

. (2006) [1935], "Corpo e Alma do Brasil: Ensaio de Psicologia Social”, in R. B. de Araújo; L. M. Schwarcz (orgs.), S. B. de Holanda, Raízes do Brasil. São Paulo, Companhia das Letras, pp. 399-420.

LAMOUNIER, Bolivar (2006), "Sérgio Buarque e os 'Grilhões do Passado'”, in R. B. de Araújo; L. M. Schwarcz (orgs.), S. B. de Holanda, Raízes do Brasil. São Paulo, Companhia das Letras, pp. 275-293.

LIMA, Luiz C. (1989), A Aguarrás do Tempo. Rio de Janeiro, Rocco.

MERQUIOR, José G. (1981), As Ideias e as Formas. Rio de Janeiro, Nova Fronteira.

MONTEIRO, Pedro M. (2012), “'Coisas Sutis, Ergo Profundas': O Diálogo entre Mario de Andrade e Sérgio Buarque de Holanda", in P. M. Monteiro (org.), M. de Andrade e S. B. de Holanda, Correspondência. São Paulo, Companhia das Letras, Instituto de Estudos Brasileiros (USP), Edusp, pp. 169-360. 


\section{Luiz Feldman}

MORSE, Richard. (1965), “Introduction”, in R. Morse (org.), The Bandeirantes: The Historical Role of the Brazilian Pathfinders. New York, Alfred A. Knopf, pp. 3-36.

NICODEMO, Thiago Lima. (2014), "Sérgio Buarque de Holanda", in L. Secco; L. B. Pericás (orgs.), Intérpretes do Brasil: Clássicos, Rebeldes e Renegados. São Paulo, Boitempo, pp. 140-152.

NOGUEIRA, Marco A. (2002), “A Diferença que Aproxima. Relendo Sérgio Buarque e Oliveira Vianna no Contrafluxo da Tradição". Tempo Brasileiro, vol. 149, pp. 25-42.

PESAVENTO, Sandra Jatahy (org.). (2005), Um Historiador nas Fronteiras: O Brasil de Sérgio Buarque de Holanda. Belo Horizonte, UFMG Editora.

RICUPERO, Bernardo. (2010), "O Conservadorismo Difícil”, in G. N. Ferreira; A. Botelho (orgs.), Revisão do Pensamento Conservador. São Paulo, Hucitec, pp. 76-94.

ROCHA, João C. de C. (2004), O Exílio do Homem Cordial: Ensaios e Revisões. Rio de Janeiro, Museu da República.

SANTOS, Wanderley G. dos. (1978), Ordem Burguesa e Liberalismo Político. São Paulo, Duas Cidades.

VIANNA, Francisco J. O. (1920), Populações Meridionais do Brasil: História - Organização Psicologia. São Paulo, Monteiro Lobato \& Cia. Editores, vol. 1.

. (1921), Pequenos Estudos de Psicologia Social. São Paulo, Monteiro Lobato \& Cia. Editores.

(1922), O Idealismo na Evolução Política do Império e da República. São Paulo, Bibliotheca d'O Estado de S. Paulo.

. (1925), O Ocaso do Império. São Paulo, Caieiras/Rio de Janeiro, Comp. Melhoramentos de São Paulo.

. (1927), O Idealismo da Constituição. Rio de Janeiro, Edição de Terra de Sol.

(1930), Problemas de Política Objetiva. São Paulo, Companhia Editora Nacional.

WAIZBORT, Leopoldo. (2011), “O Mal-Entendido da Democracia: Sergio Buarque de Hollanda, Raízes do Brasil, 1936". Revista Brasileira de Ciências Sociais, vol. 26, no 76, pp. 39-62.

WEGNER, Robert. (2000), A Conquista do Oeste: a Fronteira na Obra de Sergio Buarque de Holanda. Belo Horizonte, UFMG Editora.

. (2006), “Um Ensaio entre o Passado e o Futuro”, in R. B. de Araújo; L. M. Schwarcz (orgs.), S. B. de Holanda, Raízes do Brasil. São Paulo, Companhia das Letras.

. (2014), “As Reflexões Históricas de Sérgio Buarque de Holanda sobre Agricultura (1936-1957)". Sinais Sociais, vol. 9, pp. 107-135.

; LIMA, Nísia T. (2004), "Re-Visões do Paraíso: Ideias em Livre Concorrência". Insight Inteligência, Ano 6, no 24, pp. 20-30.

WERNECK VIANNA, Luiz. (1993), “Americanistas e Iberistas: A Polêmica de Oliveira Vianna com Tavares Bastos", in E. R. Bastos; J. Q. Moraes (orgs.), O pensamento de Oliveira Vianna. Campinas, Editora da Unicamp.

; PERLATTO, Fernando. (2011), "Iberismo e Americanismo", in A. Botelho; L. M. Schwarcz (orgs.), Agenda Brasileira: Temas de uma Sociedade em Mudança. São Paulo, Companhia das Letras. 


\section{RESUMO}

Organizar a Desordem: Raízes do Brasil em 1936

Este artigo procura reconstruir o dilema político enfrentado por Sergio Buarque de Holanda na primeira edição de Raízes do Brasil. Sustenta-se que, na montagem do argumento de seu livro de estreia, o autor entabulou diálogos intelectuais com dois importantes pensadores brasileiros, Oliveira Vianna e Gilberto Freyre. O engajamento com a obra desses autores ajudou Sergio Buarque a enunciar os aspectos negativos e positivos do tipo de sociabilidade legado pela colônia - a "cordialidade" -, a diagnosticar a incompatibilidade entre doutrinas políticas e realidade nacional e a procurar uma forma de superar essa disjunção. Aideia da "organização da desordem" reflete a dificuldade de fundar-se um Estado respeitável em uma sociedade eivada de elementos anárquicos sem reprimir o substrato cultural tradicional de sua população.

Palavras-chave: Raízes do Brasil; Sergio Buarque de Holanda; Oliveira Vianna; Gilberto Freyre; cordialidade

\section{ABSTRACT \\ Organizing Disorder: Raízes do Brasil in 1936}

This article seeks to reconstruct the political dilemma faced by Sergio Buarque de Holanda in the first edition of his work Raizes do Brasil. It argues that in the construction of the arguments contained in his debut, the author dialogued intellectually with two important Brazilian thinkers, Oliveira Vianna and Gilberto Freyre. The engagement with the works of these authors helped Sérgio Buarque delineate the negative and positive aspect of the type of sociability passed down from Brazil's colonial past - "cordiality" - and to diagnose the incompatibility between political doctrines and national reality, and also seeking how to overcome this disjunction. The idea of "organizing disorder" reflects the difficulty in founding a respectable state in a society engrained with anarchical elements without repressing the traditional cultural substrate of its population.

Keywords: Raízes do Brasil; Sergio Buarque de Holanda; Oliveira Vianna; Gilberto Freyre; cordiality 


\section{RÉSUMÉ}

Organiser le Désordre: Raízes do Brasil en 1936

Cet article cherche à reconstruire le dilemme politique qui s'est posé à Sergio Buarque de Holanda dans la première édition de Raízes do Brasil. En effet, lors de la construction de l'argument de son premier livre, l'auteur a établi des dialogues intellectuels avec deux importants penseurs brésiliens, Oliveira Vianna et Gilberto Freyre. La contribution de ces auteurs a aidé Sergio Buarque à énoncer les aspects négatifs et positifs du type de sociabilité légué par la colonie - la cordialité -, à diagnostiquer l'incompatibilité entre doctrines politiques et réalité nationale, et à chercher de quelle manière dépasser cette disjonction. L'idée d'“organisation du désordre" reflète la difficulté à fonder un État respectable dans une société entachée d'éléments anarchiques sans réprimer le substrat culturel traditionnel de sa population.

Mots-clés: Raízes do Brasil; Sergio Buarque de Holanda; Oliveira Vianna; Gilberto Freyre; cordialité

\section{RESUMEN}

Organizar el Desorden: Raízes do Brasil en 1936

Este artículo busca reconstruir el dilema político enfrentado por Sergio Buarque de Holanda en su primera edición de Raízes do Brasil. Se sostiene que, en la elaboración del argumento de su libro, el autor estableció diálogos intelectuales con dos importantes pensadores brasileños, Oliveira Vianna y Gilberto Freire. Este hecho le ayudó a enunciar los aspectos negativos y positivos del tipo de sociabilidad legado por la colonia - la "cordialidad" -, a diagnosticar la incompatibilidad entre doctrinas políticas y la realidad nacional y a buscar una forma de superación de esta disyuntiva. La idea de "organización del desorden" refleja la dificultad de fundarse un Estado respetable en un sociedad repleta de elementos anárquicos sin reprimir el substrato cultural tradicional de su población.

Palabras clave: Raízes do Brasil; Sergio Buarque de Holanda; Oliveira Vianna; Gilberto Freyre; cordialidad 